\title{
EFFECTS OF MIXED ALKALINE EARTH OXIDES IN POTASH SILICATE GLASS
}

\author{
F. I. Ashiedu ${ }^{1, *}$ and E. E. Akpan ${ }^{2}$ \\ 1 Dept. of Mechanical Engr., Federal University of Petroleum Resources, EfFurun, Delta State, NiGERIA \\ 2 Department of Mechanical EngineERIng, University of Uyo, Uyo, AKWA-IBOm STATE, NIGERIA \\ E-mail addresses:1 oyeahama1@yahoo.com,2 memetie@yahoo.com
}

\begin{abstract}
The aim of this work is to investigate the effects of mixed alkaline earth oxide in potash silicate glasses with regards to their physical properties. More recently; there has been an increase in the demand for light weight glasses which retains their physical and chemical properties for both domestic and industrial applications. The effect of mixing Alkaline earth oxide in potash silicate glass on their density, thermal properties and other physical properties has been studied. As for the method used, raw materials were collected, batch calculations were made, and the batches ( $A$ and $B$ ) were melted in an electric furnace to produce blocks of glasses. Three pieces were cut out of the block of glasses, grinded, polished and re - annealed. The re - annealed glasses were measured, for their densities, thermal, toughness, hardness, elastic moduli and brittleness. More so micrographs of the indented glasses were taken.

Results showed that mixed alkaline effect (MgO:CaO) is minimal on the densities of the A glass series while the addition of (MgO:BaO) to the glass matrix of the $B$ glass series increased its density. The crystallization temperatures of the glasses were influenced by the addition of alkaline earth oxides. The hardness and brittleness of both glass series ( $A$ and $B$ ) decreases with increasing magnesia fraction of the total alkaline earth oxide. The fracture toughness increases as the magnesia fraction of the total alkaline earth oxide increases. Conclusively, glasses of different properties depending on the desired requirement can be obtained by varying the known quantities of mixed alkaline earth oxides.
\end{abstract}

Key words: Silicate glasses, alkaline Earth oxide, crystallization temperatures, mechanical properties.

\section{INTRODUCTION}

Silicate glasses are widely used for containers, windows, doors and some other industrial applications. More recently the shift in demand from heavy to lighter glasses with excellent physical qualities is on the increase.

Therefore, it becomes necessary to obtain a desirable balance between weight, physical and other mechanical properties of silicate glasses. This research work therefore is geared towards investigating the mechanical properties of silicate glasses by mixing various alkaline earths in silicate glass. The essence of adding alkaline earth metal was to observe its effects on the mechanical, thermal properties and the densities of the respective glasses.

This study is interesting and significant in that outstanding results on the effects of mixed alkaline earth oxides on silicate glasses were obtained. A more important aspect of the study was the creation of twelve mixed alkaline earth oxide in potash silicate glasses. Their effects observed on the thermal properties with emphasis on the mechanical properties and densities on the respective mixtures. More so, the densities, the glass transition temperatures, the fracture toughness, hardness, brittleness, shear modulus, young modulus and the Poisson ratio for the twelve mixtures were established.

Extant studies showed that the production of glasses of any type requires the presence of certain elements which include the glass formers, the glass modifiers, and intermediates [1]. Similarly, for sand samples to be adequate for glass making, it must contain a minimum requirement of silicate content as shown in a study conducted using sand samples from Yarazan and Mulgubi which contains the minimum required silicate contents of $77.7 \%$ and $77.6 \%$ respectively [2]. In a related study, [3], pointed out those captions whose field strength lies between 1.5 and 2.0 (Ge, B, $\mathrm{Si}, \mathrm{P}$ ) are network formers, and that materials whose 
glass transition temperatures to glass melting ratio greater than 0.7 are good formers.

Generally, glass formers are oxides which produce glass readily. Some of the oxides that can form glasses easily are $\mathrm{B}_{2} \mathrm{O}_{3}, \mathrm{P}_{2} \mathrm{O}_{3}$ and $\mathrm{SiO}_{2}$ [4]. In a similar study, [5] observed that in an alkaline silicate, the structural units' volume remain constant with its composition. This finding was corroborated in [6]. In a related study, [7] observed that the presence of alkali chloride in a typical soda - lime - silicate glass batch up to the limit of solubility of chlorine in the melt contributes alkaline to the glass forming process. The study added that at a higher chloride concentration in the batch, a separate salt melt which is referred to as gaile is formed. Glass and gaile forms two immiscible melts.

Other factors in the formation of glasses using alkaline earth metal include the amount of non-reactive compound such as sulphates and chlorides present. The papers added that the chlorides can be up to 50 wt $\%$ of total ash content [8 - 11]. In two separate studies, [12] as well as [13] noted that near equilibrium condition, the total amount of alkaline earth oxide in the glass melt is generated by the melting temperatures only if the excess line reach phase (parting layer) is in direct contact with the melt. [14], corroborates this findings. In [18], the effects of reinforcement combinations of various hand lay-up GRP laminates of e-glasses was studied.

More so, [15] carried out a comprehensive review of the factors affecting the composition of early Egyptian glasses made from alkaline earth oxide and recommended a safe working transition temperature. Elsewhere, $[16,17]$ used evaporation studies to carry out investigation on medival glasses. The study showed a significant increase in the firing temperatures for the formation of glasses.

\section{RESEARCH METHOD}

Two batches of glass series $\mathrm{A}$ and $\mathrm{B}$ were made up of $300 \mathrm{~g}$ each. Series A was made by mixing sand $\left(\mathrm{SiO}_{2}\right)$, potassium carbonate $\left(\mathrm{K}_{2} \mathrm{Co}_{3}\right) 4 \mathrm{MgCo} 3 \mathrm{Mg}(\mathrm{OH})_{2} 5 \mathrm{H}_{2} \mathrm{O}$ and calcium carbonate $\left(\mathrm{CaCO}_{3}\right)$. While, series $\mathrm{B}$ was made by mixing sand $\left(\mathrm{SiO}_{2}\right)$, potassium carbonates $\left(\mathrm{K}_{2} \mathrm{Co}_{3}\right) 4 \mathrm{MgCo}_{3} \mathrm{Mg}(\mathrm{O} . \mathrm{H}) .5 \mathrm{H}_{2} \mathrm{O}$ and barium carbonate $\left(\mathrm{B}_{\mathrm{a}} \mathrm{C}_{03}\right)$. The effect of reinforcement combination of $\mathrm{E}$ glass was studied by [18]. The paper added that certain reinforcement combinations in a hand lay-up E-glasses, exhibits the properties of increasing strength with increasing temperature. Also, Sand, potassium carbonate $\left(\mathrm{K}_{2} \mathrm{Co}_{3}\right)$, calcium carbonate $\left(\mathrm{CaCO}_{3}\right)$, barium carbonates $\left(\mathrm{BaCO}_{3}\right)$.and anhydrous magnesium carbonate $4 \mathrm{MgCo}_{3} \mathrm{Mg}(\mathrm{O} . \mathrm{H})_{2}$. $5 \mathrm{H}_{2} \mathrm{O}$ were used as sources for $\left(\mathrm{SiO}_{2}, \mathrm{~K}_{2} \mathrm{O}, \mathrm{CaO}, \mathrm{BaO}\right.$, and $\mathrm{MgO}$. The batch composition by mole is shown in Table 1 .

Table 1: Batch composition by mole for the formation of

\begin{tabular}{|c|c|c|}
\hline Series & Glass System & Composition \\
\hline \multirow{6}{*}{ A } & I & $60 \mathrm{SiO}_{2} 20 \mathrm{~K}_{2} \mathrm{O} .20 \mathrm{CaO}$ \\
\hline & Ii & $60 \mathrm{SiO}_{2} 20 \mathrm{~K}_{2} \mathrm{O} .4 \mathrm{MgO} .16 \mathrm{CaO}$ \\
\hline & Iii & $60 \mathrm{SiO}_{2} 20 \mathrm{~K}_{2} \mathrm{O} .8 \mathrm{MgO} 0.12 \mathrm{CaO}$ \\
\hline & Iv & $60 \mathrm{SiO}_{2} 20 \mathrm{~K}_{2} \mathrm{O} .12 \mathrm{MgO} .8 \mathrm{CaO}$ \\
\hline & $\mathrm{V}$ & $60 \mathrm{SiO}_{2} 20 \mathrm{~K}_{2} \mathrm{O} .16 \mathrm{MgO} .4 \mathrm{CaO}$ \\
\hline & $\mathrm{Vi}$ & $60 \mathrm{SiO}_{2} 20 \mathrm{~K}_{2} \mathrm{O} .20 \mathrm{MgO}$ \\
\hline \multirow{6}{*}{ B } & I & $60 \mathrm{SiO}_{2} 20 \mathrm{~K}_{2} \mathrm{O} .20 \mathrm{BaO}$ \\
\hline & Ii & $60 \mathrm{SiO}_{2} 20 \mathrm{~K}_{2} \mathrm{O} .4 \mathrm{MgO} 0.16 \mathrm{BaO}$ \\
\hline & Iii & $60 \mathrm{SiO}_{2} 20 \mathrm{~K}_{2} \mathrm{O} .8 \mathrm{MgO} 0.12 \mathrm{BaO}$ \\
\hline & Iv & $60 \mathrm{SiO}_{2} 20 \mathrm{~K}_{2} \mathrm{O} .12 \mathrm{MgO} .8 \mathrm{BaO}$ \\
\hline & $\mathrm{V}$ & $60 \mathrm{SiO}_{2} 20 \mathrm{~K}_{2} \mathrm{O} .16 \mathrm{MgO} .4 \mathrm{BaO}$ \\
\hline & vi & $60 \mathrm{SiO}_{2} 20 \mathrm{~K}_{2} \mathrm{O} .20 \mathrm{MgO}$ \\
\hline
\end{tabular}

To achieve homogeneity, each batch was weighed using precision weighing scale, then dried. For ease of identification, each dried mixed sample were labeled and placed in small sample bags. This was done to prevent, contaminations of the various samples in addition to easy identification and control. The mixed alkaline earth oxide was represented by the general formula $60 \mathrm{SiO}_{2} \cdot 20 \mathrm{~K}_{2} \mathrm{O}$ XMO. $(20-\mathrm{X}) \mathrm{RO}$. X from the relation, is in mole per cent and is given as $0,4,8,12,16$ and 20. The different series of glass A and B were produced by varying the concentration of the mixed alkaline oxide ( $\mathrm{MgO}, \mathrm{CaO}$, or $\mathrm{MgO} ; \mathrm{BaO})$ and adding this to the fixed glass matrix $\left(60 \mathrm{SiO}_{2}\right.$. and $\left.20 \mathrm{~K}_{2} 0\right)$.

Melting: clean platinum crucible was used to melt the various batches at a temperature of $1400^{\circ} \mathrm{C}$ using electric furnaces for a period of one hour. The melt (product) was stirred for four hours using platinum paddle. To produce the desired glass blocks, the mutter glass was poured into a rectangular pre-heated steel mould after five hours of melting: immediately after this, the melt was placed into an electric furnace for an hour at $560^{\circ} \mathrm{C}$ then allowed to cool to room temperature at $1^{\circ} \mathrm{C}$ per minute.

Glass Cutting:- Each glass bulk was cut into two smaller pieces of $20 \mathrm{~mm}$ by $20 \mathrm{~mm}$ by $10 \mathrm{~mm}$ in size using an isomet 5000 linear precision saw (a water cooled low speed diamond saw) with a blade speed of 4000 revolution per minute, feed rate of $4.0 \mathrm{~mm} / \mathrm{m}$ and thickness of $0.635 \mathrm{~mm}$. The cut pieces were then air dried to remove water and prevent surface deterioration by hydration. 
Table 2: Weight of the raw material used for $100 \mathrm{~g}$ of glass

\begin{tabular}{|c|c|c|c|c|c|c|}
\hline \multirow{2}{*}{ Series } & \multirow{2}{*}{ Glass system } & \multicolumn{5}{|c|}{ Weight of raw material for $100 \mathrm{~g}$ glass } \\
\hline & & $\mathrm{SiO}_{2}$ & $\mathrm{~K}_{2} \mathrm{CO}_{2}$ & $4 \mathrm{MgCO}_{3} \cdot \mathrm{Mg}(\mathrm{OH}) 2.5 \mathrm{H}_{2} \mathrm{O}$ & $\mathrm{CaCO}_{3}$ & $\mathrm{BaCO}_{3}$ \\
\hline \multirow{6}{*}{ A } & 1 & 54.54 & 41.78 & -- & 30.28 & -- \\
\hline & 2 & 55.06 & 42.18 & 5.93 & 24.46 & -- \\
\hline & 3 & 56.60 & 42.59 & 11.98 & 18.52 & -- \\
\hline & 4 & 54.47 & 43.01 & 18.15 & 12.47 & -- \\
\hline & 5 & 56.70 & 43.43 & 24.44 & 6.29 & -- \\
\hline & 6 & 57.26 & 43.87 & 30.86 & -- & -- \\
\hline \multirow{6}{*}{ B } & 1 & 42.10 & 32.28 & -- & -- & 46.12 \\
\hline & 2 & 44.48 & 34.08 & 4.79 & -- & 38.96 \\
\hline & 3 & 47.11 & 36.09 & 10.15 & -- & 30.94 \\
\hline & 4 & 50.07 & 38.36 & 16.19 & -- & 21.92 \\
\hline & 5 & 53.43 & 40.93 & 23.03 & -- & 11.70 \\
\hline & 6 & 57.26 & 43.87 & 30.86 & -- & -- \\
\hline
\end{tabular}

Density Measurement: Using Archimedes principle, the densities of each glass was ascertained. The weights of the samples were taken three times to reduce measurement error in air and in distilled water. Similarly, the temperature of manometer was recorded accordingly. The densities of each glass was calculated using the relationship

$$
\rho=\frac{M_{A} \rho_{\text {water }}}{M_{A}-M_{W}}
$$

In (1), $M_{A}$ is the mass of object in air, $M_{W}$ is the mass of object in water and $\rho$ is the density of water

\subsection{Mechanical Testing:-}

The edges of the glass were grounded using $120 / 240 / 400 / 800$ and 1200 water cooled grits of silicon carbide. The grounded glass pieces were polished using 6/3/ and $\mathrm{Nm}$ diamond paste. The sample were rinsed in water and dried after the polishing operation. In order to remove residual stresses, re-annealing at $560^{\circ} \mathrm{Cat}$ one hour was carried out. The glass pieces were cooled to room temperature at $1^{\circ} \mathrm{C}$ per minute. The residual stresses removed were confirmed using Polaris cope. When the glass sample had completely cooled down, one face was tested using Mitutoyo Hm 101 vickers Microhardness indenter. The loads used for the test were $0.3,0.5,1.0,2.5,5.0$ and $10 \mathrm{~kg}$ respectively. While the waiting time was pegged at 20 seconds, five indents were administered for each sample.

The Vickers indention hardness, $H_{v}$ was calculated using

$$
H_{v}=\frac{1.854 p}{d^{2}}
$$

In (2), $p$ is the applied load and $d$ is the indent diagonal.
The total length of the crack growth extending from the diagonals of each indent was measured and remeasured after 24 hour interval. The fracture toughness was estimated using

$$
K_{k}=\frac{0.824 P}{C^{3 / 2}}
$$

In (3), $C$ is the length of crack and $K_{k}$ is the fracture toughness

Similarly, the brittleness (B) was calculated using the expression

$$
B=\frac{H_{v}}{K_{k}}
$$

\subsection{Optical Microscopy}

Micrographs of indentations for glass series A and B were taken. $1 \mathrm{~kg}$ and $5 \mathrm{~kg}$ loads were placed on the stage. Objective lenses were focused on the objectives revolver with magnification of 20 and 10 for $1 \mathrm{~kg}$ and $5 \mathrm{~kg}$ respectively. Using coarse and fine adjustments wheel, the samples were focused. The micrographs of these indents were taken on the axiom vision EE camera and saved at a $100 \mu \mathrm{m}$ scale on the computer.

\section{RESULTS}

\subsection{Density Measurements}

Density was measured for two different glass series system (A and B) by using the Archimedes method. The series $A$ and $B$ averaged glass densities are presented in Table 3. The glass series $\mathrm{B}$ ( $\mathrm{MgO}-\mathrm{BaO})$ indicated the highest density, while glass series $\mathrm{A}$ values of density were comparatively lower. There was a significant decrease in the glass densities ol the $\mathrm{B}$ series with decreasing $\mathrm{Ba} 0$ vvhlle the densities of the A glass series decreased slightly with decreasing $\mathrm{CaO}$. 


\subsection{Differential Thermal Analysis (DTA)}

Differential thermal analysis was used to obtain the A and $B$ glass series, glass transition and crystallization temperatures. The (glass temperature of transition) $\mathrm{Tg}$ was taken at the point where an endothermic activity was first noticed, similarly the (crystallization temperatures) $\mathrm{T}$ were read at the initiation of the exothermic peak. The values for these temperatures (crystallization and glass transition) were presented in Table 2. Values obtained for the crystallization temperature of the series A glass ( $\mathrm{MgO}$ and $\mathrm{CaO}$ ) are the highest when compared with those of the $\mathrm{B}$ series glasses ( $\mathrm{MgO}$ and $\mathrm{BaO}$ ). The exotherniic and endothermic peaks for series A glass appear well defined, while those of the series B glass were unnoticeable. The Tg values of the series B glass were comparatively lower than those of series A glass. In glass series $B$, the higher exothermic peak was found within the single alkaline base glass (BVI) while the peak of higher endothermic event was found amongst the mixed alkaline earth oxide B series glass, the $\mathrm{Tg}$ of the $\mathrm{B}$ series glass seemed to be increasing with the decreasing ratio of $\mathrm{BaO}: \mathrm{MgO})$. Both the exothermic and endothermic features of the B series glass were highly indistinct. There was also an increase in crystallization temperatures of the B series glass with decreasing ( $\mathrm{BaO}: \mathrm{MgO}$ ) ratio.

In series A glass, the single alkaline earth oxide base glasses has higher glass transition temperature than the mixed alkaline earth oxide glasses. Results of series A glass [)TA showed that the exothermic activities (peaks) with decreasing ( $\mathrm{CaO}: \mathrm{MgO}$ ) ratio were much more sharper and intense when compared to those of the series B glass. Apart from AIV and AV glasses that do not have obvious exothermic peaks, all series A glasses have very high exothermic peaks while Alto AIV have small endothermic peaks.

Table 3: The Average Densities of Series A and B Glass

\begin{tabular}{llll}
\hline Series & Glass system & Composition & Average Density $\left(\mathrm{G} / \mathrm{m}^{3}\right)$ \\
\hline \multirow{3}{*}{ A } & I & $60 \mathrm{siO}_{2} .20 \mathrm{~K}_{2} \mathrm{O} .20 \mathrm{CaO}$ & $2.5962 \pm 0.0003$ \\
& II & $60 \mathrm{siO}_{2} .20 \mathrm{~K}_{2} \mathrm{O} .4 \mathrm{Mgo} .16 \mathrm{CaO}$ & $2.5743 \pm 0.0002$ \\
& III & $60 \mathrm{siO}_{2} .20 \mathrm{~K}_{2} \mathrm{O} .8 \mathrm{mg} .12 \mathrm{Cao}$ & $2.5210 \pm 0.0000$ \\
& IV & $60 \mathrm{siO}_{2} .20 \mathrm{~K}_{2} \mathrm{O} .12 \mathrm{MgO} .8 \mathrm{CaO}$ & $2.5163 \pm 0.0003$ \\
& V & $60 \mathrm{siO}_{2} .20 \mathrm{~K}_{2} \mathrm{O} .16 \mathrm{MgO} .4 \mathrm{CaO}$ & $2.4985 \pm 0.0002$ \\
& VI & $60 \mathrm{siO}_{2} .20 \mathrm{~K}_{2} \mathrm{O} .20 \mathrm{MgO}$ & $2.4652 \pm 0.0003$ \\
\hline I & $60 \mathrm{siO}_{2} .20 \mathrm{~K}_{2} \mathrm{O} .20 \mathrm{BgO}$ & $3.1655 \pm 0.0049$ \\
& II & $60 \mathrm{siO}_{2} .20 \mathrm{~K}_{2} \mathrm{O} .4 \mathrm{MgO} .16 \mathrm{BaO}$ & $3.0355 \pm 0.0022$ \\
$\mathrm{III}$ & $60 \mathrm{siO}_{2} .20 \mathrm{~K}_{2} \mathrm{O} .8 \mathrm{MgO} .12 \mathrm{BaO}$ & $2.9057 \pm 0.0007$ \\
$\mathrm{~B}$ & $60 \mathrm{siO}_{2} .20 \mathrm{~K}_{2} \mathrm{O} .12 \mathrm{MgO} .8 \mathrm{BaO}$ & $2.6062 \pm 0.0013$ \\
& IV & $60 \mathrm{siO}_{2} .20 \mathrm{~K}_{2} \mathrm{O} .16 \mathrm{MgO} .4 \mathrm{BaO}$ & $2.5438 \pm 0.0007$ \\
& V & $60 \mathrm{siO}_{2 .} 20 \mathrm{~K}_{2} \mathrm{O} .20 \mathrm{MgO}$. & $2.4654 \pm 0.0003$ \\
\hline
\end{tabular}

Table 4: Values for onset glass transition $\left(T_{G}\right)$ and onset crystallization temperature

\begin{tabular}{|c|c|c|c|c|}
\hline Series & Glass System & Compoisition & $\mathrm{T}_{\mathrm{G}} \pm 100^{\circ} \mathrm{C}$ & $\mathrm{T}_{\mathrm{C}} \pm 100^{\circ} \mathrm{C}$ \\
\hline \multirow{6}{*}{ A } & I & $60 \mathrm{SiO}_{2} .20 \mathrm{~K}_{2} 0.20 \mathrm{CaO}$ & 620 & 797 \\
\hline & II & $60 \mathrm{siO}_{2 .} 20 \mathrm{~K}_{2} \mathrm{O} .4 \mathrm{MgO} .16 \mathrm{CaO}$ & 615 & 804 \\
\hline & III & $60 \mathrm{siO}_{2 .} 20 \mathrm{~K}_{2} \mathrm{O} .8 \mathrm{MgO} 0.12 \mathrm{CaO}$ & 610 & 811 \\
\hline & IV & $60 \mathrm{siO}_{2 .} 20 \mathrm{~K}_{2} \mathrm{O} .12 \mathrm{MgO} .8 \mathrm{CaO}$ & 619 & 805 \\
\hline & $\mathrm{V}$ & $60 \mathrm{siO}_{2 .} 20 \mathrm{~K}_{2} \mathrm{O} .16 \mathrm{MgO} .4 \mathrm{CaO}$ & 551 & 807 \\
\hline & VI & $60 \mathrm{siO}_{2 .} 20 \mathrm{~K}_{2} \mathrm{O} .20 \mathrm{MgO}$ & 629 & 885 \\
\hline \multirow{6}{*}{ B } & I & $60 \mathrm{siO}_{2 .} 20 \mathrm{~K}_{2} \mathrm{O} .20 \mathrm{BaO}$ & 536 & 719 \\
\hline & II & $60 \mathrm{siO}_{2 .} 20 \mathrm{~K}_{2} \mathrm{O} .4 \mathrm{MgO} .16 \mathrm{BaO}$ & 557 & 792 \\
\hline & III & $60 \mathrm{siO}_{2 .} 20 \mathrm{~K}_{2} \mathrm{O} .8 \mathrm{MgO} .12 \mathrm{BaO}$ & 560 & 792 \\
\hline & IV & $60 \mathrm{siO}_{2 .} 20 \mathrm{~K}_{2} \mathrm{O} .12 \mathrm{MgO} .8 \mathrm{BaO}$ & 574 & 776 \\
\hline & V & $60 \mathrm{siO}_{2 .} 20 \mathrm{~K}_{2} \mathrm{O} .16 \mathrm{MgO} .4 \mathrm{BaO}$ & 583 & 802 \\
\hline & VI & $60 \mathrm{siO}_{2 .} 20 \mathrm{~K}_{2} \mathrm{O} .20 \mathrm{MgO}$ & 629 & 885 \\
\hline
\end{tabular}


Table 5: Mechanical properties of series A and B glasses

\begin{tabular}{|c|c|c|c|c|c|c|c|c|}
\hline SERIES & Glass system & Composition & $\mathrm{K}_{\mathrm{k}} M N m^{3 / 2}$ & $\mathrm{H}_{\mathrm{v}} G p a$ & Bum 12 & $\begin{array}{l}\text { Е Gpa } \\
( \pm 0.1)\end{array}$ & $\mathrm{G}( \pm 0.1)$ & $\begin{array}{l}\mathrm{V} \\
( \pm 0.1) \\
\end{array}$ \\
\hline \multirow{6}{*}{ A } & I & $60 \mathrm{SiO}_{2} .20 \mathrm{~K}_{2} \mathrm{O} .20 \mathrm{CaO}$ & $0.60 \pm 0.01$ & $4.63 \pm 0.30$ & $7.72 \pm 0.52$ & 66.58 & 26.38 & 0.262 \\
\hline & II & $60 \mathrm{siO}_{2 .} 20 \mathrm{~K}_{2} \mathrm{O} .4 \mathrm{MgO} 0.16 \mathrm{CaO}$ & $0.61 \pm 0.01$ & $4.51 \pm 0.12$ & $7.39 \pm 0.23$ & 66.16 & 26.33 & 0.256 \\
\hline & III & $60 \mathrm{siO}_{2 .} 20 \mathrm{~K}_{2} \mathrm{O} .8 \mathrm{Mg} 0.12 \mathrm{CaO}$ & $0.61 \pm 0.01$ & $4.46 \pm 0.19$ & $7.31 \pm 0.33$ & 65.24 & 2.6 .04 & 0.253 \\
\hline & IV & $60 \mathrm{siO}_{2 .} 20 \mathrm{~K}_{2} \mathrm{O} .12 \mathrm{MgO} .8 \mathrm{CaO}$ & $0.62 \pm 0.01$ & $4.43 \pm 0.20$ & $7.15 \pm 0.34$ & 64.31 & 25.70 & 0.251 \\
\hline & V & $60 \mathrm{siO}_{2 .} 20 \mathrm{~K}_{2} \mathrm{O} .16 \mathrm{MgO} .4 \mathrm{CaO}$ & $0.66 \pm 0.01$ & $4.42+0.08$ & $6.70 \pm 0.16$ & 63.28 & 25.32 & 0.25 \\
\hline & VI & $60 \mathrm{siO}_{2 .} 20 \mathrm{~K}_{2} \mathrm{O} .20 \mathrm{MgO}$ & $0.67 \pm 0.02$ & $4.23+0.07$ & $6.31+0.22$ & 59.83 & 23.92 & 0.251 \\
\hline \multirow{6}{*}{ B } & I & $60 \mathrm{siO}_{2 .} 20 \mathrm{~K}_{2} \mathrm{O} .20 \mathrm{BaO}$ & $0.53 \pm 0.02$ & $4.41+0.33$ & $8.23+0.70$ & 58.28 & 22.70 & 0.284 \\
\hline & II & $60 \mathrm{siO}_{2 .} 20 \mathrm{~K}_{2} \mathrm{O} .4 \mathrm{MgO} .16 \mathrm{BaO}$ & $0.52 \pm 0.01$ & $4.39 \pm 0.07$ & $8.44 \pm 0.21$ & 58.32 & 22.92 & 0.272 \\
\hline & III & $60 \mathrm{siO}_{2 .} 20 \mathrm{~K}_{2} \mathrm{O} .8 \mathrm{Mg} 0.12 \mathrm{BaO}$ & $0.58 \pm 0.01$ & $4.37 \pm 0.11$ & $7.53 \pm 0.23$ & 61.15 & 24.18 & 0.264 \\
\hline & IV & $60 \mathrm{siO}_{2 .} 20 \mathrm{~K}_{2} \mathrm{O} .12 \mathrm{MgO} .8 \mathrm{BaO}$ & $0.63 \pm 0.01$ & $4.33 \pm 0.10$ & $6.87 \pm 0.19$ & 60.72 & 24.17 & 0.256 \\
\hline & V & $60 \mathrm{siO}_{2 .} 20 \mathrm{~K}_{2} \mathrm{O} .16 \mathrm{MgO} .4 \mathrm{BaO}$ & $0.65 \pm 0.03$ & $4.28 \pm 0.09$ & $6.58 \pm 0.33$ & 55.62 & 22.00 & 0.264 \\
\hline & VI & $60 \mathrm{siO}_{2 .} 20 \mathrm{~K}_{2} \mathrm{O} .20 \mathrm{MgO}$ & $0.67 \pm 0.02$ & $4.23 \pm 0.07$ & $6.31 \pm 0.22$ & 59.83 & 23.92 & 0.251 \\
\hline
\end{tabular}

\section{MECHANICAL TESTING}

Each glass piece was tested for its mechanical properties Fracture toughness, hardness and brittleness values were measured by micro indentation while the elastic moduli (Young's modulus, Shear modulus, Poisson ratio) were measured by using ultrasonic technique. The values calculated for indentation fracture toughness, micro hardness, brittleness, shear modulus, Young's modulus and Poisson ratio were represented in Table 5. Similarly, Table 5 shows clearly the mechanical properties of the potash silicate glass: (hardness, indentation toughness, brittleness, Young's modulus, shear moJulus and Poisson ratio) against the fraction of magnesia of the alkali earth oxide sum for the series A and B (all of mixed alkaline earth).

These mechanical properties -toughness, hardness, elastic moduli and brittleness- were plotted against the magnesia fraction of the sum of the mixed alkaline earth oxide content for the two series of glass (A and B) which all contain mixed alkaline earth oxide.

In glass series $\mathrm{A}$, the brittleness, hardness and elastic moduli (Young's modulus, shear modulus and Poisson ratio) all decreased as the content of magnesia increased, while the fracture toughness for this series of glass increased with increasing magnesia content. A similar pattern was observed for. the hardness, brittleness and fracture toughness of B series glass. The brittleness and hardness decreased with the increasing magnesia content whil the fracture toughness increased as the content of magnesia increased'. The elastic moduli of the glass series B took on an oddly irregular pattern. Initially as the magnesia content increased, the elastic moduli were increasing (Bi, Bli, and Bill) then it started decreasing (BIV) and finally increased (BVI). It was suspected that the reason why this may have happened was because of an error in the source of raw material used for the magnesia. The partial replacement of larger ion of alkaline earth $(\mathrm{CaO}, \mathrm{BaO})$ tlorn smaller ion of alkaline earth $(\mathrm{MgO})$ does not increase the modulus. On the average, the hardness values for glass series B which contain the larger ion, is comparatively lower than those of glass series A whose calcium ion is smaller than that of barium ion. This is because barium ions are heavier, so the brittleness of the barium containing glass is expected to be higher than that of calcium which is the case as seen in Table 4; B series glass has the maximum brittleness. The hardness ranking for the series $A$ and $B$ glass is of the order of series $A>$ series $B$. The fracture toughness values for the series B glass appeared to be lower than expected even though both glass series show a continuous increase with increasing magnesia content.

Hardness, toughness, brittleness, Young's modulus, shear modulus and Poisson ratio were plotted against the 'calcia + baria' molar ratio to silica for both series $\mathrm{A}$ and $\mathrm{B}$ glasses. The brittleness of the series A glass was increasing as the molar ratio of $(\mathrm{CaO}+\mathrm{BaO})$ to that of Si02 increased, this trend was similar to that of the B series glass. The hardness of both series A and B glass was found to increase with increasing (calcia + baria/ silica) content. Fracture toughness for both glasses decreased with increasing (calcia + banal silica) content.

The elastic moduli (Young's modulus, shear modulus and Poisson ratio) of the series A glass increased with the $(\mathrm{CaO}+\mathrm{BaOl} \mathrm{Si02})$ content, but those of the glass series B displayed a rather irregular pattern.

\section{CONCLUSION}

The effect of mixing alkaline earth oxide in potash silicate glass on their density, thermal properties and 
most importantly its mechanical properties have been studied in 12 different silicate glasses. The mixed alkaline effect (MgO:CaO ) showed very minimal effect on the densities of the A glass series. The addition of (MgO: $\mathrm{BaO}$ ) to glass matrix of the $\mathrm{B}$ series glass significantly increased its density. The addition of ( $\mathrm{MgO}: \mathrm{CaO}$ ) in the series A glass increased their glass transition temperatures, however, these additions of mixed alkaline (AII, AIII, AIV, AV) earth when compared to (AI, AVI) all of single alkaline earth, lowered the glass transition temperature. These mixed alkaline earth additions also influenced the crystallization temperatures of the glasses. Both series $A$ and $B$ glasses exhibited the same behaviour with fracture toughness, hardness and brittleness, where their hardness and brittleness decreased with increasing magnesia content while their fracture toughness increased as the magnesia content increased. The elastic moduli of the series A glasses decreased with increasing magnesia, but those of the $B$ series glasses had a random and irregular behaviour with increasing magnesia.

Generally speaking, there were slight improvements in the mechanical properties of both glass series (A and B). Glasses of mixed alkaline earth had better mechanical properties than those of their single alkaline counterpart. Improvement in the mechanical property depends on what purpose the glass is intended to serve (that is whether it is to be used for ordinary glasses which can tolerate stresses of about $2.6 \mathrm{Mpa}$ or high quality glasses). However, this improvement will contribute immensely in building ideas that will further the silicate glass production for future applications.

\section{REFERENCES}

[1] Doremus R. H. Glass science $-2^{\text {nd }}$ Ed., Wiley, New York, 1994.

[2] Duvuna G. A. and Ayuba A, A Study on Silica Sand Quality in Yazaran and Mulgulbi Deposit for Glass making, Nigerian Journal of Technology, Vol 34 No 1, jan. 2015, pp. $109-112$.

[3] Rouxel, T. Elastic properties and short - to - medium range order in glasses. Journal of the American Ceramic Society, 90 (10), 2007, pp. 3019 - 3039.

[4] Rocherulle, J. Elastic moduli of oxynitride glasses: Extension of Makishima and Machenzie's theory Journal of Non - Crystaline solids, vol 108 (2), 1989. Pp. 187 - 193.
[5] Tromans, D. and Meech J. A. Fracture toughness and surface energies of minerals; theoritical estimate for oxides, sulphide, silicates, and halides in minerals. Engineering, vol, 15 (12), 2002, pp. 1027 - 1041.

[6] Doweidar, H. Density structure correlations in $\mathrm{Na}_{2} \mathrm{O}-$ $\mathrm{Al}_{2} \mathrm{O}_{3}-\mathrm{SiO}_{2}$ glasses, Journal of non-crystalline solids, 240 (1 - 3), 1998, pp 55 - 65.

[7] Tanimoto Sakoto and Thilo Rehren. Interactions between silicate and salt melts in LBA glass making, Journal of Archaeological Science, vol. 35, 2008, pp. 2566 - 2573.

[8] Jackson. C. M Booth, C. A.. and Smedley, Glass by design? Raw materials, recipes and compositional data. Archaeometry, 47, 2005, pp 781 - 795

[9] Tite, M. S, Shortland, A. J., Maniatis, Y., Kavoussanaki, D, and Harris S. A. The composition of soda - rich and mixed alkaline plant ashes used in the production of glass. Journal of Archeological science vol. 33, 2006 pp. $1284-1292$.

[10] Jackson. C. M. and Smedley, J. W. Medieval and post medieval glass technology; melting characteristics of some glasses melted from vegetable ash and sand mixtures. Glass Technology, 45 (1), 2004, pp. $36-42$

[11] Shuger A. and Rehren T. H. Formation and composition of glasses as a function of firing temperatures. Glass Technology, 43c, 2002, pp 145 150.

[12] Bingham, P. A. and Marshall, M. Reformation of container glasses for environtal benefit through lower melting temperatures, Glass techn. Vol 46 (1), 2005, pp $11-19$

[13] Gerth, K. Wedepohl, K. H. and Heide, K, Experimental melts to explore the technique of medieval wood ash glass production and the chlorine contents of medieval glass types. Chemie der Erde, 58, 1998, pp $219-232$.

[14] Rehren T. H. Ramesside glass colouring crucibles. Archaeometryvol 39, 1997, pp. 355 - 368.

[15] Rehren T. H. A review of factors affecting the composition of early Egyptian Glasses and faience: alkali and alkali earth oxides. Journal of Archaeological Science. vol. 35, 2008, pp 1345-1354.

[16] Shoer, B. and Rehren, T. H. The composition of glasses and associated ceramics. Journal of glass studies. vol. 42, 2007. pp.13-23.

[17] Beerkens, R. C. and Van Limpt, J. Evaporation in Industrial Glass melt furnances. Glasstech, Ber. 2001, 74 (9). Pp 245 - 572.

[18] Edelugo, S. O. Effects of reinforcement combination on mechanical strength of reinforced plastic (GRP) hand lay-up laminates under increased temperature conditions, Nigerian Journal of Technology, Vol. 23, No. 1, 2004, pp. 39-47. 